\title{
Biobank(ing): tanker om praktiske retningslinjer ved innsamling av materialer til biomarkører
}

\author{
Peter Kierulf \\ FoU-seksjonen, Klinisk kjemisk avdeling, Ullevål universitetssykehus, 0407 Oslo \\ E-post: peter.kierulf@medisin.uio.no Telefon: 92285111
}

\begin{abstract}
SAMMENDRAG
Artikkelen gir forskere som skal i gang med innsamling av materialer til undersøkelser av biomarkører enkelte praktiske anvisninger med henvisning til litteratur som kan gi utdypende informasjon.
\end{abstract}

\author{
Kierulf P. Biobank(ing): Thoughts on practical guidelines for collecting material for biomarkers. \\ Nor J Epidemiol 2006; 16 (1): 51-52.
}

\section{ENGLISH SUMMARY}

This paper suggests advices to researchers that are to start collection of biological samples to be used for biomarkers with particular reference to guidelines that may be of assistance.

\section{INNLEDNING}

Biomarkører og biobankvirksomhet henger nøye sammen, kanskje ikke like klart for alle. Forståelse av at en biobank er en potensiell (utømmelig) kunnskapskilde er på vei inn i norsk medisin. Vi kunne si at prøver fornuftig innsamlet og lagret $\mathrm{i}$ biobank er som "gull i banken". Man vil kunne drive gold-mining i lang tid fremover hvis forholdene er lagt godt til rette. Denne artikkelen tar sikte på å gi kortfattet informasjon og rettledning til forskere som gir seg i kast med innsamling av prøvematerialer som skal brukes til biomarkørundersøkelser.

\section{TANKER OM PRAKTISKE RETNINGSLINJER VED INNSAMLING AV MATERIALER TIL BIOMARKØRER}

Med økende innsikt i celle- og molekylærbiologi og med økende generell forståelse av at biologiske substanser i større eller mindre grad er "levende" molekyler, biomolekyler, har kravene til prøvetaking og prøvehåndtering og prøveoppbevaring stadig økt. I tillegg er de siste år Lov om biobank (1) gjort gjeldende. Alle disse forhold innebærer at den som skal i gang med å samle inn prøver til en biobank må ta mange hensyn. Det vil være både klokt og nødvendig å ta kontakt med ekspertise som kan gi råd i god tid før prosjektet skal starte, aller helst fra prosjektets første planlegging. Svært mye nyttig praktisk kunnskap er nedfelt $i$ oversiktsartikkelen til Holland og medarbeidere (2). Logistikk og formatering i prøvetaking, prøvehåndtering, prøvelagring og prøveanalysering og prøvegjenfinning er komplisert og må inngå fra tidligste stadium i prosjektplanleggingen. Det meste er komplisert fordi det gis så mange valgsituasjoner som man må forstå konsekvensene av. Det siste er vanskelig. En ekspert i feltet, en som er trenet i å tenke preanalytisk, analytisk og postanalytisk (oftest fra fagfolk innen laboratoriefagene som medisinsk biokjemi, mikrobiologi, blodbank eller patologi) vil her være til uvurderlig hjelp. Den største ekspertisen vil etter hvert finnes hos dem som allerede har satt opp og driver en biobank. Et spesielt viktig punkt når det gjelder hva og hvordan prøver skal håndteres for senere best mulig "gold-mining" er at man tidlig i prosjektet som prosjektleder orienterer seg mot hvor forskningsfronten innen biomarkører i det aktuelle forskningsfelt befinner seg. Utviklingen går nemlig her så hurtig at biobanking av EDTA-fullblod til DNA-undersøkelser, og plasma, serum, spinalvæske og urin til småmolekylære markørsubstanser og proteiner, hormoner, cytokiner og vekstfaktorer osv. i dag bør suppleres med materialer (celler) som kan undersøkes på genekspresjon (evt. på global genekspresjonsplattform) eller på enklere plattformer med RealTime Reverse Transkriptase Polymerase Chain Platform. Det er også viktig i prosjektets planlegging å vite at spesifikke, interessante celler før nedfrysning kan ren-isoleres (3) (blant annet High Speed Sorting Flow Cytometry), som ved blant annet minimal recidual disease ved cancer residiv. Slike celler kan undersøkes på spesifikke DNA-forandringer eller RNA-transkripter. Bioviabel nedfrysning av isolerte, interessante celler vil også kunne finne sted, med mulighet for senere opptining og funksjonalitetsundersøkelser (4). Også fullblod kan nedfryses (5) for senere EBV transformering av interessante celler til "udødelige" cellelinjer som fryses $i$ alikvoter. Teknologien flytter seg her raskt og forutsatt gode tanker i forkant av prosjektstart vil en biobank kunne levere materialer i verdensklasse i lang tid. Det bør sannsynligvis ikke være fantasien, men pengene som setter stopper for ens gullgraving. God biobankpraksis vil dog være fundamentet (6). 


\section{REFERANSER}

1. Lov: biobanker (http://www.odin.dep.no/detalj/RUS200320030204HODNORTRYK/bn!15900001.html).

2. Holland NT, et al. Biological sample collection and processing for molecular epidemiological studies. Mutat Res 2003; 543: 217-234.

3. Li B. A strategy to identify genomic expression at single-cell level or a small number of cells. Electr $J$ Biotechnol 2005; 8 (1): 71-81.

4. Hori $\mathrm{S}$, et al. Freeze-thawing procedures have no influence on the phenotypic and functional development of dendritic cells generated from peripheral blood CD14+ monocytes. J Immunother 2004; 27: 27-35.

5. Hayes RB, et al. Whole blood cryopreservation in epidemiological studies. Cancer Epidemiol Biomarkers Prev 2002; 11: 1496-1498.

6. ISBER (International Society for Biological and Environmental Repositories). Best practices for repositories I: collection, storage and retrieval of human biological materials for research. Cell Preserv Technol 2005; 3: 548. 